\title{
La función pública española con especial referencia a los funcionarios de Administración local con habilitación de cáracter nacional
}

\author{
Francisco Javier Jiménez Lechuga
}

\begin{abstract}
Sumario: I. INTRODUCCIÓN. II. El LIBRE ACCESO A LAS FUNCIONES PÚBLICAS DE LOS CIUDADANOS CONFORME AL ARTÍCULO 23.2 C.E. III. LOS PRINCIPIOS DE MÉRITO, CAPACIDAD, LIBRE CONCURRENCIA Y PUBLICIDAD EN EL ACCESO A LA FUNCIÓN PÚBLICA Y LAS GARANTÍAS EN EL MANTENIMIENTO DEL CARGO. IV. LOS FUNCIONARIOS DE ADMINISTRACIÓN LOCAL CON HABILITACIÓN DE CARÁCTER NACIONALY SU DIFÍCIL MOVILIDAD EN LOS ÚLTIMOS TIEMPOS: A) DISCRECIONALIDAD ADMINISTRATIVA, B) CONCEPTOS JURÍDICOS INDETERMINADOS. V. LA SENTENCIA DEL TSJA DE 23 DE JUNIO DE 2003 (SALA DE LO CONTENCIOSO-ADMINISTRATIVO DE GRANADA, SECCIÓN PRIMERA). VI. CONCLUSIONES. VII. BIBLIOGRAFÍCA.
\end{abstract}

\section{INTRODUCCIÓN}

Uno de los temas más debatidos del Derecho público desde el advenimiento del Estado moderno por políticos, sociólogos y juristas ha sido y es la organización de los empleados públicos y, más sencillamente, el régimen jurídico de la función pública ${ }^{1}$. Así, sin que un arreglo completo del funcionariado se haya conseguido nunca en ningún país de nuestro entorno, es lo cierto que, salvo las excepciones que después se dirán y que son muy matizadas, se ha pasado de un sistema venal o otro de acceso a cargos públicos en atención a principios constitucionales de capacidad, mérito, libre concurrencia y publicidad. Dentro de este avance que se ha conseguido durante el siglo XX, es lo cierto que han funcionado dos sistemas de función pública diferentes: uno cerrado o de carrera y otro abierto o de selección de personal que era reclutado al servicio de la función pública con carácter oportunista y con un fuerte clientelismo (el spoil system). Ha escrito recientemente en relación con todo esto A. MARTínEZ MARín que el primer modelo se cimenta sobre la carrera que, según el mismo autor, puede ser definida como el itinerario profesional establecido en la Administración a toda persona para que, a partir de su ingreso, según unas pruebas objetivas reglamentadas, pueda realizar una progresión de ascenso superando las exigencias profesionales positivadas en

${ }^{1}$ M. Weber, Escritos politicos, Folios Ediciones, México, 1982. 
reglas generales, impersonales e igualitarias. El sistema está concebido para que la persona ingrese de joven en la función pública y en ella permanezca toda su vida, y de ahí la necesidad de que en ésta encuentre un régimen de promoción y de ascensos que le posibilite, aportando méritos y/o superando pruebas, «correr» del grado inferior al superior y del cuerpo de menor al de mayor categoría hasta el más alto nivel establecido. Afirma también con acierto A. MARTínez MARín que el modelo de la carrera referido es europeo y su más claro ejemplo se encuentra en el sistema francés y en los que reciben su inuujo como el español y el belga ${ }^{2}$, en el alemán, y sobre todo en el propio de la Unión Europea, Suecia, Suiza y Holanda que son también ejemplos europeos más próximos al modelo de empleo abierto, yendo Italia últimamente también por este camino $^{3}$.

El modelo de función pública abierta es, como he indicado, más propio del Derecho anglosajón y, sobre todo, del estadounidense. Este modelo propicia un modo de reclutamiento diferente en cuanto, en líneas generales, no existe predeterminado un sistema de pruebas selectivas y unos exámenes rigurosos que acrediten la suficiencia de quienes acceden a un cargo público funcionarial como ya he dicho que sucede en el Derecho francés. Así, el político vencedor de las elecciones -especialmente en Estados Unidos- suele renovar las plantillas mediante personas próximas a su partido y a través de la contratación laboral y no la relación estatutaria propia del Derecho galo. A. MARTínEZ MARín afirma, en relación con este extremo, que la Administración suele actuar como un empresario que contrata personal para cubrir unos puestos de trabajo precisos y diferenciados, teniendo sólo en cuenta la diferenciación o, mejor, adecuación competencial de la persona al perfil del empleo ofrecido. Añade el autor al que sigo ahora que el empleo público, que se regula por un contrato laboral, se extinguirá cuando su tarea sea innecesaria o no sea ejercida con la competencia exigida. La Administración no debe preocuparse de la formación de su personal, de darle su estatuto funcionarial que le garantice un régimen jurídico diferenciado de aquél que regule las relaciones laborales de los demás trabajadores de las empresas privadas del país y los conflictos que se susciten se ventilarán ante la jurisdicción ordinaria.

Palomar Olmeda, no considera el sistema abierto de función pública como posible y lo contrapone con el laboral, pero no desde el sentido en

\footnotetext{
2 J.R. Parada VÁzquez, Derecho Administrativo, 3 vols., Ed. Marcial Pons, Madrid, 2000. Yo comparto la opinión de este autor y me inclino por el modelo francés de función pública.
}

3 A. Martínez Marín, Régimen jurídico de los funcionarios, Ed. Técnos, Madrid, 2001. 
que lo hace al autor anterior -que es más correcto- sino sólo en el sentido de que los instrumentos que ofrece el Derecho laboral no son suficientes para garantizar el ejercicio de funciones públicas (exclusión de ley aplicable, principio de no norma mínima, principio de norma más favorable, la condición más beneficiosa adquirida y la negociación colectiva), aunque esta exposición no sea enteramente defendible pues una cosa es la indefinición del modelo de función pública española en la actualidad y, de otro lado, otra muy distinta el hecho de que exista personal laboral al servicio de las Administraciones públicas, hecho éste que siempre será necesario y saludable aunque en su justa medida ${ }^{4}$.

Este último sistema que es prototípico de los Estados Unidos se ha visto allí favorecido por unos factores específicos a los que sólo he aludido anteriormente que no se han dado en otros lugares. El Estado americano carecía de tradición estatal, se vertebra federalmente, se cimenta sobre principios democráticos inicialmente antiburocráticos, concibe la gestión de las Administraciones públicas como la de las empresas privadas, posee un alto desarrollo socio-económico y cuenta, en consecuencia, con un gran número de universidades y centros de estudios, así como de grandes empresas que posibilitan el intercambio laboral de las personas entre las Administraciones y las empresas públicas y entre éstas y las privadas ${ }^{5}$.

Por otra parte, aunque las primeras normas en tomo a la función pública española se dictan ya a mediados del siglo XIX, hay que reconocer, no obstante, que el gran desarrollo de ambos sistemas (cerrado y abierto) han conocido su desarrollo durante el siglo XX. Así, en España, el Real Decreto de 18 de junio de 1852 («Estatuto de Bravo Murillo») es el primer Estatuto de la función pública en Europa ${ }^{6}$ sin olvidar tampoco la normativa dictada por López Ballesteros aunque su práctica posterior -siempre según A. MARTínez MARíN- fue muy limitada, debido sobre todo a la departamentalización ministerial, la dispersión de cuerpos especiales y el nombramiento y cese político de empleados públicos, aunque todos estos males fueron en su momento objeto de crítica doctrinal. Es el propio ministro autor de la reforma quien sigue seis años más tarde denunciando el gran número de empleados públicos cesantes por cambios políticos y la urgente e imprescindible necesidad de establecer «reglas para el ingreso en las carreras públicas, reglas para ascender, reglas para conservar a los

\footnotetext{
4 A. Palomar Olmeda, Derecho de la función pública (régimen jurídico de los funcionarios públicos), Ed. Dykinson, Madrid, 2000.

5 J. De CRUZ Ferrer, La función pública superior en Estados Unidos, INAP, Madrid, 1984.

6 J. ZILLIER, Les Administrations comparées, Montchrestien, París, 1993.
} 
empleados y que no puedan ser separados arbitrariamente, sino por motivos justos fundados»?

La Ley de 22 de Julio de 1918 y su reglamento de 7 de septiembre del mismo año (Estatuto de Antonio Maura) es el siguiente paso trascendental en la definición de lo que será, finalmente, la función pública española aunque su promulgación llega precisamente en un tiempo de convulsiones políticas e inestabilidad social que hacen dudar a muchos observadores de la época de su real, eficacia. La persecución de la estabilidad en el empleo y el régimen retributivo, así como el sistema de acceso a cuerpos y escalas, son los objetivos de esta norma que se prolongará durante medio siglo con algunas modificaciones de tono menor. Las características generales de este Estatuto de Maura -que ha estudiado muy bien MARTínez MARín en un libro que tuve el gusto de comentar hace ya algún tiempo- son las siguientes: a) el personal se clasifica en dos cuerpos: el técnico y el auxiliar. El primero se divide en tres categorías (jefe de administración, jefes de negociado y oficiales) y cada una de estas tres clases. El segundo constituye igualmente una categoría y ser vertebra en tres clases, b) la oposición se generaliza como forma de ingreso en la función pública, y el ascenso se realiza según los criterios de antigüedad, oposición y libre designación pudiendo el Consejo de Ministros acordar discrecionalmente la cesantía o separación del servicio de cualquier funcionario o auxiliar, aunque sólo por exigencias del servicio y posibilitando el recurso contenciosoadministrativo contra dicha resolución, c) se establece la jubilación forzosa a los sesenta y siete años y la voluntaria a los sesenta y cinco, cuando los interesados llevan cuarenta de servicio o antes si justifican una imposibilidad física, y d) se regulan los derechos pasivos de jubilación retiro, viudedad y orfandad, y se establece el derecho de asociación funcionarial, aunque haciéndolo depender de la aprobación ministerial.

Fundamental es el Decreto 315/1964, de 7 de febrero, por el que se aprueba el Texto Articulado de la Ley de Funcionarios Civiles del Estado que viene a regular -ya en plena Dictadura franquista- al funcionariado español, intentando dividirlos en Cuerpos Generales y Espaciales, fijar sus retribuciones o conceptos retributivos, adquisición y pérdida de la condición de funcionario público, situaciones administrativas de los mismos, modo de acceso, la jubilación de los funcionarios y la carrera administrativa de los mismos. La reforma, en principio, puede calificarse de positiva, aunque presentaba, para mi personal punto de vista, dos graves defectos, por una parte, la fuerte laboralización del personal al servicio de las Admi-

7 Bravo Murillo, Diario de sesiones de Cortes, Congreso de los Diputados, Legislatura de 1858. 
nistraciones públicas y, de otra, la elección de un modelo híbrido entre el sistema cerrado de función pública (francés) y el sistema americano o abierto (spoils system) que a lo largo de los años se agudizaron. Además, un cierto clientelismo subsistió y aún subsiste hasta la década de los años ochenta, si bien es verdad que este problema todavía ha empeorado con el advenimiento de las Comunidades Autónomas cuyas plantillas constituyen el peor ejemplo que de modelo fragmentado de función pública pueda ofrecerse $^{8}$. Algún autor opina respecto de esta trascendental Ley que los aciertos pueden concretarse en los siguientes extremos: a) la constitución de la Comisión Superior de Personal, que instauraba, por primera vez, la centralización de la política de personal, b) la reestructuración de las retribuciones y su homologación para todos los funcionarios de los Cuerpos Generales y Especiales y, sobre todo, eliminando, la retribución extrapresupuestaria de los funcionarios a través de las tasas y las exacciones parafiscales, y, c) por último, el intento de racionalización en materias de provisión de puestos de trabajo, plantillas orgánicas, etc., si bien, todo ello se realizó sobre la perspectiva y tomando como referencia el cuerpo de pertenencia y no el propio funcionario, lo cual limitaba el planteamiento?.

Más adelante está el Real Decreto-ley 22/1977, de 30 de marzo que es un hito importante en este camino y reforma la estructura de las retribuciones funcionariales y el régimen de incompatibilidades y la Ley 30/1984 de 2 de agosto, de Medidas Urgentes para la Reforma de la Función Pública que adapta -aunque muy parcialmente, desde luego- al texto constitucional el sistema de función pública y que, más tarde, fue declarado parcialmente inconstitucional por la STS 99/1987, de 11 de junio, dictándose posterior mente la Ley 23/1988, de 28 de julio, que adoptó algunos extremos de la anterior Ley al dictado del TC impidiendo alguna que otra flagrante «deslegalización» ${ }^{10}$.

La Ley 22/1993, de 29 de diciembre marca un hito más en la desmembración del sistema de función pública española con una liberalización del personal al servicio de la Administraciones públicas y una discrecionalidad próxima a la arbitrariedad. Las reformas siguen en esta línea de desmembración (Ley 14/2000) y el panorama no puede ser más sombrío ${ }^{11}$.

\footnotetext{
8 J.L. PIÑAR MARAÑóN, «La estructura de representación y participación del personal al servicio de las Administraciones públicas», REDA n. ${ }^{\circ}$ 65/1990.

9 F. Garrido Falla, Reforma de la función pública, Madrid, 1985.

10 F. Garrido Falla, «Los funcionarios públicos y el derecho a la libre expresión», $R A P$ n. ${ }^{\circ}$ $63 / 1970$.

11 L. Morell OCAÑA, «La función pública y la habilitación nacional», Documentos INAP, Madrid, n. ${ }^{\circ} 12 / 1997$.
} 


\section{EL LIBRE ACCESO DE LOS CIUDADANOS A LAS FUNCIONES PÚBLICAS CONFORME AL ARTÍCULO 23.2 DE LA CONSTITUCIÓN}

Es claro que tras la Constitución española de 27 de diciembre, están sentadas las bases y las líneas maestras sobre las que ha de dibujarse el nuevo estatuto de la función pública española. No está claro, empero, cómo es posible, según denunció A. NiETo García hace dos años, que veinticinco años después de promulgada aquélla, no dispongamos todavía de un modelo de función pública definido (que ha de ser estatutario) y que la caótica situación por la que atraviesa toda la función pública todavía no resuelta y habiéndose convertido en una incuestionable e inaplazable cuestión de Estado cuya situación no puede ni debe prolongarse por más tiempo $^{12}$. Ya el Tribunal Constitucional tuvo que poner orden en este panorama desolador que presenta hoy nuestra función pública. Es necesario, por tanto, destacar que en cuanto a la remisión a las leyes que hace el artículo 23.2 C.E. para regular los requisitos de cargos y funciones públicas, ha de ponerse en conexión con lo relativo al rango o tipo de norma que debe regular tal acceso con las previsiones que la C.E. establece para unos u otros cargos y funciones ${ }^{13}$ :

- Los requisitos para acceder a cargos electivos de representación política a través de procesos electorales, debe regularse mediante ley orgánica, de acuerdo con el artículo 81 C.E. ${ }^{14}$.

- Los de la designación de las Mesas de las Cámaras Legislativas por los reglamentos de las mismas ${ }^{15}$.

- Los de acceso a la función pública de las Cortes Generales en el Estatuto del personal al que se refiere el art. 72.1 C.E. ${ }^{16}$, norma que debería equipararse a la ley en el sistema de fuentes ${ }^{17}$.

- En cuanto a los requisitos de acceso a cargos y funciones de la Administración pública, no constituye desarrollo del artículo 23.2

\footnotetext{
12 A. Nieto GarcíA, El arbitrio judicial, Ed. Ariel, Barcelona, 2000.

13 STC 47/1990, de 20 de marzo.

14 STC 47/1990, de 20 de marzo. Ctr. también F. SÁinz MorenO, «El Estatuto de la función pública después de la STC 99/1987, de 11 de junio y de la ley 23/1988, de 28 de julio», RAP n. ${ }^{\circ} 127 / 1988$.

15 STC 47/1990, de 20 de marzo.

16 STC 47/1990, de 20 de marzo.

17 STC 13/1988, de 8 de julio.
} 
C.E., a los efectos de la exigencia de ley orgánica, la regulación de los requisitos comunes necesarios para 108 procedimientos de selección para el acceso a cargos y funciones públicas de carácter no electivo ${ }^{18}$. Es más, de la relación entre los artículos 23.2 y 103.3 C.E. se deriva que esta reserva de ley no excluye en términos absolutos todo tipo de remisión legislativa al reglamento, que podrá completar o particularizar en aspectos instrumentales y con la debida sujeción, la ordenación legal en la materia, pues sería ¡lógico exigir del legislador una previsión de los requisitos para acceder a cada cargo, ya que aquéllos han de variar sustancialmente en cada caso! ${ }^{19}$.

- Ahora bien, el legislador no podrá hacer remisiones incondicionadas al reglamento, ni éste podrá ignorar o sustituir a la $l e y^{20}$, ya que de lo dispuesto en los artículos 23.2 y 103.3 C.E. resulta que hay que entender constitucionalmente prohibida la posibilidad de que la Administración pueda incorporar, mediante la vía reglamento o de actos de aplicación de la ley, pueda incorporar nuevos y diferentes requisitos que los legalmente previstos en los procedimientos de acceso a la función pública. Y si el legislador no prevé un desarrollo reglamentario de los requisitos de acceso por él regulados, estará sancionado un criterio igualitario que el reglamento no podrá desconocer, restringiendo o agravando las condiciones de acceso ${ }^{21}$. Algún autor ha destacado también suficientemente esto ${ }^{22}$.

\section{LOS PRINCIPIOS DE MÉRITO, CAPACIDAD, LIBRE CONCURRENCIA Y PUBLICIDAD EN EL ACCESO A LA FUNCIÓN PÚBLICA Y LAS GARANTIAS DE MANTENIMIENTO EN EL CARGO}

Que la Administración no puede contratar con quien quiera, es un aserto concodio y aceptado por la ciudadanía. Que la Administración, a

\footnotetext{
18 SIC 99/1987, de 11 de junio.

19 STC 47/1990, de 20 de marzo.

20 STC 47/1990, de 20 de marzo.

21 STC 47/1990, de 20 de marzo.

22 A. MARtínez Marín, Régimen Jurídico de los funcionarios, Ed. Tecnos, Madrid 2001 y A. MARTÍNEZ MARín, Funcionarios locales con habilitación (pasado, presente y futuro), Ed. Tecnos, Madrid, 1999. Vid. también mi comentario al primero de los libros citados en $R A A P$ n. ${ }^{\circ} 46 / 2002$, pp. 547 y ss.
} 
la hora de reclutar a su personal -tanto funcionario como laboral-, debe someterse a un procedimiento previamente establecido es otra verdad de Perogrullo. Que la Administración, finalmente, en la contratación de personal a su servicio, así como en la realización de obras y servicios de toda clase, ha de respetar los principios de capacidad y mérito, libre concurrencia, publicación y publicidad, es algo que tampoco hoy nadie niega de la naturaleza especial de las funciones que desempeña la Administración pública que no es, como resulta evidente, sino el brazo ejecutor o el instrumento puesto al servicio del Estado para la consecución de los principios de éste. En las sociedades modernas, dada la complejidad organizacional y relacional que presentan, el lado de las garantías del ciudadano, por muy denostada que pueda estar esta postura, se presenta como inevitable y la lucha contra las inmunidades del poder se ha vuelto así -aunque los maestros del Derecho todavía vivos no lo hayan podido intuir enteramente- tarea irrenunciable y fin de toda actividad no sólo científica sino también práctica. En otras palabras, la justicia es el fin de todo jurista y la Administración pública (o el Estado, según se prefiera) no es sino uno de los personajes en el escenario jurídico o, todo lo más, un justiciable cualificado. Otra idea distinta de la concepción expuesta puede dar lugar a abusos que un Estado social y democrático de Derecho no puede en ninguna forma consentir ${ }^{23}$. Por eso de la función pública también se he ocupado con cierta extensión el Tribunal Constituciona ${ }^{24}$. Por eso la doctrina del derecho de acceso a funciones públicas en condiciones de igualdad (art. 23.2 C.E.) y de acuerdo con los principios de mérito y capacidad (art. 103.3 C.E.) recibe una importante precisión al afirmarse que aquel derecho y estos valores constitucionales operan con distinto rigor e intensidad según se trate del acceso a la función pública o del desarrollo o promoción de la carrera administrativa, ya que siendo el derecho recogido en el artículo 23.2 C.E. un derecho de configuración legal, puede la Administración legítimamente dentro de los concursos para la provisión de vacantes o puestos de trabajo entre personas que ya han accedido a la función pública, y acreditado por tanto los requisitos de mérito y capacidad tener en cuenta otros criterios distintos que no guarden relación con éstos, en atención a una mayor eficacia en la organización de los servicios o a la protección de otros bienes constitucionales ${ }^{25}$. Por eso mismo, las pruebas restringidas convocadas para el acceso a la función pública y/o la consolidación de del puesto de trabajo han de considerarse como un procedimiento pros-

\footnotetext{
23 L. Parejo Alfonso, Constitución y valores del ordenamiento, Madrid, 1990.

24 STC 99/1987, de 11 de junio.

25 STC 192/1991, de 14 de octubre y STC 200/1991, de 28 de octubre.
} 
crito por el artículo 23.2 C.E., sin perjuicio de que en determinados casos excepcionales la diferencia de trato establecida en la ley pueda considerarse como razonable, proporcionada y no arbitraria, al aparecer esta diferenciación como un medio excepcional y adecuado para resolver una situación también excepcional, expresamente prevista en una norma con rango de ley con el objeto de alcanzar una finalidad constitucionalmente legítima, entre las que se encuentra la propia eficacia de la Administración pública ${ }^{26}$. En todo caso, la admisibilidad de estas pruebas restringidas, aun cuando el legislador estatal las haya previsto para casos singulares, debe ser francamente excepcional y objeto de una interpretación restrictiva ${ }^{27}$.

Por otra parte, la publicación de las convocatorias de acceso ha de ser lo suficientemente eficaz para que se cumplan los principios y fines del procedimiento de selección $\mathrm{y}$, desde el punto de viste de los aspirantes al empleo público, para servir al acceso en condiciones de igualdad a la función pública. Esta convocatoria debe provocar la concurrencia y facilitar la divulgación, pero dentro de estos criterios, su instrumentación no es necesariamente única ${ }^{28}$.

Por otra parte, pero conectado con lo anterior, al igual que el principio general de igualdad, esta concreción o especificación del mismo en relación con el acceso a cargo o funciones públicas realizada en el artículo 23.2 C.E. actúa en dos planos distintos; de un lado como igualdad ante le ley o en aplicación de la ley y, de otro lado, como igualdad en la ley. Y este segundo aspecto de igualdad en la ley significa para el legislador no sólo la prohibición de establecer diferencias que carezcan de una fundamentación objetiva y razonable, sino también, en el ámbito de la función pública y en conexión con el artículo 103.3 C.E., la prohibición de establecer diferencias que no guarden relación con los principios de mérito y capacidad ${ }^{29}$. Así, cuando al TC se plantee una queja por discriminación de los supuestos contenidos en el artículo 23.2 C.E., y siempre que la diferenciación impugnada no se deba a alguno de los criterios explícitamente

\footnotetext{
${ }^{26}$ STC 27/1991, de 14 de febrero, que considera constitucionalmente admisible las pruebas específicas de acceso a la función pública anteriormente fijadas por leyes estatales y autonómicas, a las que sólo tienen acceso el personal al servicio de la Comunidad Autónomas, como interino o contratado, al ser medidas de carácter excepcional y transitorio para resolver un proceso irrepetible, el de la carrera de la función pública autonómica, sin que exista tiempo para poder acudir a las formas normales de acceso a la función pública.

27 STC 151/1992, de 19 de octubre.

${ }^{28}$ STC 85/1983, de 25 de octubre.

29 STC 27/1991, de 14 de febrero.
} 
implicados en el artículo 14 C.E., será el artículo 23.2 C.E. el que haya de ser considerado de modo directo para apreciar si el acto impugnado ha desconocido el principio de igualdad ${ }^{30}$. También hay que tener en cuenta que el artículo 23.2 C.E. reconoce expresamente en su último inciso que la ley puede sujetar el acceso a cargos y funciones públicas a determinados requisitos, por lo que el derecho fundamental en el consagrado no es un derecho indiscriminado, sino un derecho de configuración legal, dentro siempre del respeto a los principios y preceptos constitucionales ${ }^{31}$. No se lesionan, pues -al menos esto se deduce de la doctrina del TC-, el artículo 23. 2 C.E. si la exigencia de los requisitos establecidos con carácter general por las leyes se aplica motivadamente con criterios razonables y en términos de generalidad que excluyen toda idea de discriminación personal, o que supongan, por parte de la Administración restricciones innecesarias para el ejercicio de este derecho fundamental, debiendo prevalecer en todo caso la interpretación más favorable a la efectividad del derecho fundamental ${ }^{32}$. Por ello, se ha considerado en muy diversos casos que no vulnera ni el principio de igualdad ni el derecho de acceder a cargos y funciones públicas la negativa de la Administración a otorgar un empleo público, por no cumplirse los requisitos que para acceder a los cargos y funciones públicas exigen las leyes vigentes, siempre que tales requisitos, por supuesto, no vulneren ningún derecho ni principio constitucionalmente garantizado ${ }^{33}$.

Para finalizar con este apartado, como es natural, la cuestión más debatida ha sido la de los principios de mérito y capacidad como criterio de acceso a la función pública. Que tal mandato del artículo 103.3 es aplicable a todas las Administraciones públicas (y en singular a la función pública local) $)^{34}$ es algo que no puede ponerse en cuestión, si bien sus exigencias no comportan un determinado esquema uniforme de Comisiones seleccionadoras ${ }^{35}$. Cierto que el nivel de titulación y los años de servicios tienen alcance básico; pero la omisión en una disposición de una Comunidad Autónoma de determinados aspectos básicos contenidos en una Ley del Estado no supone su insplicabilidad ni por tanto su inconstitucionali-

\footnotetext{
30 STC 192/1991, de 14 de octubre, 200/1991, de 28 de octubre y 217/1992, de 1 de diciembre.

31 STC 104/1991, de 13 de mayo.

32 STC 73/1989, de 20 de abril.

33 STC 217/1992, de 1 de diciembre.

34 A. MARTínez Marín, Funcionarios locales con habilitación (pasado, presente y futuro), Ed. Técnos, Madrid, 1999 y STC 85/1983, de 25 de octubre.

35 STC 54/1982, de 26 de julio.
} 
dad $^{36}$. Dentro del marco constitucional es el legislador quien ha de concretar los requisitos oportunos ${ }^{37}$. El y la propia Administración tienen un amplio margen de libertad para dotar de contenido concreto en cada caso a un concepto jurídico indeterminado como es el de mérito y capacidad ${ }^{38}$. En singular, no es arbitrario que se estime como mérito para el acceso a plazas administrativas de nivel superior el estar ocupando otras inferiores; la medida, lejos de ser contraria a la Constitución, es conforme con ella, dado el mandato del artículo 35 de favorecer le promoción mediante el trabajo ${ }^{39}$.

El derecho a permanecer en el cargo, finalmente, ha sido también objeto de varios pronunciamientos del Tribunal Constitucional. En efecto, partiendo de una interpretación sistemática de la C.E., el derecho a acceder a cargos públicos comprende también el derecho a permanecer en los mismos, pues de otro modo quedaría vacío de contenido ${ }^{40}$. Es, además, un derecho a permanecer en el cargo en condiciones de igualdad, con los requisitos que señalen las leyes, derecho éste que será susceptible de amparo si las leyes establecen una causa de remoción que viole un derecho fundamental diferente. Por tanto implica el derecho a no ser removido de los cargos o funciones públicas de cualquier género a los que se accedió previamente, si no es por las causas y de acuerdo con el procedimiento legalmente establecido. Existen sobre esta cuestión varios pronunciamientos del Tribunal Constitucional como ya he indicado ${ }^{41}$.

\section{LOS FUNCIONARIOS DE ADMINISTRACIÓN LOCAL CON HABILITACIÓN DE CARÁCTER NACIONAL Y SU DIFÍCIL MOVILIDAD EN LOS ÚLTIMOS TIEMPOS: a) DISCRECIONALIDAD ADMINISTRATIVA, b) CONCEPTOS JURÍDICOS INDETERMINADOS}

La historia de estos antiguos cuerpos de funcionarios locales ha sido estudiada -aunque no con la extensión y detalle que les mismos merece-

\footnotetext{
36 STC 10/1989, de 24 de enero.

37 STC 50/1986, de 23 de abril.

38 A. Martínez Marín, Funcionarios locales con habilitación (pasado, presente y futuro), Ed. Tecnos, Madrid, 1999.

39 STC 73/1990, de 26 de abril.

40 STC 7/1992, de 16 de enero.

41 STC 133/1989, de 19 de julio.
} 
rían- por algunos autores ${ }^{42}$. Para el interesado por estos temas, la época o período más conocido es el constitucional, aunque no hay que olvidar que ya en el municipio romano había esta clase de funcionarios y que luego pasaron a ser reales Escribanos durante el Absolutismo. Lógicamente, la fe pública se especializó, naciendo Cuerpos de Secretarios judiciales, los Notarios y 109 Secretarios de los altos órganos del Estado. Es el artículo 320 de la Constitución de Cádiz, de 19 de marzo de 1812, la que recoge la figura del Secretario del Ayuntamiento del que todas las Corporaciones de este tipo deben dotarse y que es elegido por mayoría de votos de las mismas y pagado por estas y, curiosamente, el propio Ayuntamiento los remueve pero ha de ser con la aprobación de la Diputación provincial. Tienen como misión la actualización y custodia del registro civil, es fedatario de todos los acuerdos municipales, ordena y custodia el archivo de todos los acuerdos, expedientes, órdenes y demás papeles asumiendo también en esta temprana fecha funciones interventoras que todavía conservan los de esta Subescala en la actualidad. En ésta época, sin embargo, como ha apuntado certeramente MARTínez MARín el sistema de acceso que predomina en estos funcionarios es el de spoils system ${ }^{43}$.

Otra etapa más en la historia del Secretariado local lo constituyen las Leyes Municipal y Provincial de 8 de enero de 1845 -de corte claramente autoritario y conservador-. Estos cargos siguen siendo de nombramiento de las mismas autoridades referidas y la separación se realiza por la propia Corporación mediante expediente motivado dando cuenta al Gobierno para que resuelva ${ }^{44}$. El Depositario, en cambio, es removido libremente por la Corporación, desapareciendo el Síndico y entrando en escena también el Secretario particular del Alcalde (que no es, por tanto, figura hoy tan novedosa como pudiera parecer en principio) y las funciones siguen siendo en esencia las mismas. El bienio progresista supone algunas modificaciones aunque se conserva la legislación moderada a que he hecho referencia y, por consiguiente, el régimen jurídico de los Secretarios y Depositarios de los Ayuntamientos y Diputaciones provinciales ${ }^{45}$. Los militares desempeñan en este periodo un papel preponderante (Espartero, Narváez, O’Donnell, Prim, Serrano, Primo de Rivera y Franco). Se dicta la Ley de Ayuntamientos de 5 de

\footnotetext{
42 J.J. FernándeZ-ViLla y Dorbé, El Secretariado de Administración local, Madrid, 1968.

43 A. MARTínez Marín, Funcionarios locales con habilitación (pasado, presente y futuro), Ed. Tecnos, Madrid, 1999.

44 A. Nieto García, Los primeros pasos del Estado constitucional, Ed. Ariel, Barcelona, 1996.

45 E. CORRAL GARCíA, «Los secretarios: pasado, presente y futuro», Revista de Estudios Locales (CUNAL), n. ${ }^{\circ} 12 / 1996$.
} 
julio de 1856 que pierde vigor después de la disolución de las Cortes Generales por Decreto de 16 de octubre de 1956, volviéndose a la legislación de 1845 ya referida. Hay que tener en cuenta que por estos años de del siglo XIX va fraguando la Administración del Estado y su Administración Periférica, lo que hasta entonces era toda una novedad en nuestra organización administrativa, por lo que son figuras fundamentales en este tiempo -ya había tenido lugar la reforma de Javier de Burgos- el Gobernador Civil, una Diputación y un Consejo Provincial con funciones consultivas y sobre todo contencioso-administrativas (y esto no hay que olvidarlo porque es especialmente trascendente en la historia de nuestra justicia administrativa) que algún autor ha estudiado con detenimiento en España en épocas recientes ${ }^{46}$.

Más tarde se producen reformas con la Ley de 25 de septiembre de 1863 en que se fortalece la figura del Secretario de le Diputación y del Consejo Provincial así como del Contador de Fondos y del Depositario que la Ley de Presupuestos y Contabilidad Provincial de 20 de septiembre de 1865 se encarga de destacar especialmente. El Depositario de fondos provinciales es ahora nombrado por el Ministerio de la Gobernación debiendo prestar la correspondiente fianza. En estas reformas se ve la mano de J. Posada Herrers y la configuración del sistema de Administración local es en exceso conservadora y coartadora de las libertades locales por mucho que algún autor recientemente haya querido hacemos ver lo contrario o, por lo menos, haya presentado el autor como un «prócer» de la patria.

Pasado este período, la Ley municipal y la provincial, de 20 de agosto de 1870 consagra ahora al Secretario como al empleado municipal más importante siendo nombrado por el Ayuntamiento entre los españoles mayores de edad y que posean la instrucción primaria siendo destituido por la propia Corporación con quórum especial de dos tercios. Sus misiones son las de asistencia y preparación de sesiones sin voz y sin voto (esto último es ridículo), redacción del acta, preparador y fedatario de las resoluciones y acuerdos municipales además de Jefe de los funcionarios pertenecientes a la Secretaría. También existe la posibilidad de nombramiento de Secretarios particulares para los Ayuntamientos capitales de provincia y los de cierta densidad de población ${ }^{47}$. Para la Diputación se

\footnotetext{
46 A. NiETo García, Estudios históricos sobre Administración y Derecho Administrativo, INAP, Madrid, 1986 y A. Gallego ANaBiarTe, Formación y enseñanza del Derecho público en España (1.769-2000). Ed. Marcial Pons, Madrid, 2002.

${ }^{47}$ M. ABELLA, La regulación provisional del régimen local, El Consultor de los Ayuntamientos, Madrid, 1982.
} 
establecen nuevamente los cargos de Secretario, Contador y Depositario $^{48}$.

En este íter legislativo continúan las Leyes municipal y provincial de 20 de octubre de 1877 , modificada esta última por la de 29 de agosto de 1882. Esta vez los poderes de destitución del Secretario pasan al Gobernador civil que puede hacerlo dando cuenta al Gobierno y previo informe favorable del Consejo de Estado (más justo es decir oyendo al interesado y al Consejo de Estado). El nombramiento y libre cese de estos empleados públicos es reestablecido nuevamente por la citada Ley de 1882 (art. 104). Resulta curioso saber que por Real Decreto de 11 de diciembre de 1900 se aprueban los Reglamentos de Secretarios y de Depositarios, por un lado, y él de Contadores provinciales y municipales de fondos, por otro $^{49}$. El Estatuto de Maura da un espaldarazo a la creación de los Cuerpos Nacionales que reciben su consagración en la Ley municipal republicana de 31 de octubre de 1935. Antes, naturalmente, cabe destacar la obra de Calvo Sotelo durante la Dictadura de Primo de Rivera con la promulgación de los Estatutos Municipal y Provincial de 1924 y 1925, respectivamente $^{50}$. En este período se fortalecen y especifican hasta la extenuación las funciones de estos funcionarios y se dictan los conocidos extensos y técnicos reglamentos («que son de una rara perfección técnica, al igual que los franquistas» como ya he indicado en algún otro lugar que ahora no recuerdo). En esta época se crean también los Colegios provinciales y la colegiación obligatoria para estos funcionarios además de un Montepío que, no hay que olvidarlo, todavía no tenían otros muchos cuerpos funcionariales. El Cuerpo de Directores de Bandas de Música se crea precisamente durante el período republicano aunque hoy haya desaparecido según ya sabemos.

Otro aspecto importante que destaca el profesor MARTínEZ MARín respecto de los Secretarios de Administración local durante el período republicano es la inamovilidad que estos consiguen, con independencia de las «purgas» políticas que se produjeran posteriormente con arreglo a las depuraciones de los vencedores sobre los vencidos. Dice que la inamovilidad se asegura, al igual que en la legislación anterior, con la exigencia de las mayorías cualificadas exigidas. La Ley no establece el régimen estatutario de los miembros de estos cuerpos; pero sí recuerda la responsabilidad administrativa, civil y penal a que están sometidos y la obligada

48 Bullón Ramírez, Historia del Secretariado de Administración local, Abella, Madrid, 1968.

49 J. Gascón y Marín, Tratado de Derecho Administrativo, Madrid 1947.

50 J.L. CuETO, et alli, «Los secretarios de las Corporaciones locales», RVAP n. ${ }^{\circ}$ 20/1988. 
advertencia de ilegalidad, así como su comunicación al Gobernador civil, en el supuesto presuntamente infractor, como modo de quedar exonerado de ella. Crea la Ley republicana un Montepío de funcionarios y una Escuela de Funcionarios de Administración Local, lo que, para la época, resulta novedoso ${ }^{51}$.

La Dictadura franquista supone uno de los períodos más negros para la vida democrática de los funcionarios locales y de las propias Corporaciones locales salidas de la Guerra Civil. Antes de decir las cosas tan duras que seguirán contra la legislación de Régimen local y del régimen político franquista, tango que reconocer, al menos, una cosa. Es claro que los funcionarios locales -especialmente los llamados muy certeramente Secretarios de Administración local- conocieron un período de tranquilidad, estabilidad en el empleo e independencia en o frente al poder local que nunca antes había disfrutado. Si uno de estos funcionarios era nombrado para un Ayuntamiento (y lo digo yo que jamás trabajé en Ayuntamientos franquistas), era seguro que las funciones a desempeñar por el funcionario estaban totalmente seguras y era el propio Gobernador civil quien podría ampararle aunque yo sé bien que esto convenía al régimen de Franco. Hoy, por el contrario, la indefinición de estos Cuerpos y la duda sobre su futura existencia, así como su poco peso específico dentro de un Ayuntamiento, hacen pensar que su papel sea irrelevante. Y hay otra cosa aún peor. El hecho de que, disciplinariamente, dependan en última instancia de la Administración del Estado (lo que seguramente desaparecerá tras su regionalización o provincialización, incluso) no significa nada, ya que, finalmente, por banderías políticas, o por el elemental principio de autoconservación, seguramente la Administración del Estado vendrá en confirmar las decisiones de los municipios y el funcionario se verá en la cuerda floja sin que ni siquiera los Colegios Profesionales vengan en su ayuda. Quien esto afirma tiene ya alguna experiencia.

Me vuelvo nuevamente al estudio del funcionariado local durante el franquismo (período a la vez tan próximo y tan lejano). La depuración empieza con la Ley de 10 de febrero de 1939, que ordena investigar el pasado de los funcionarios y su grado de adhesión al Movimiento Nacional. Se instruyen unos expedientes que, finalmente, en alzada, son resueltos por el Ministerio de la Gobernación, procediéndose posteriormente a la convocatoria de plazas por Ley de 25 de agosto de 1939 que convocó el 80 por 100 de las plazas existentes en todas las Administraciones públicas.

\footnotetext{
51 A. MARTínez Marín, Funcionarios locales con habilitación (pasado, presente y futuro), Ed. Tecnos, Madrid, 1999.
} 
Por supuesto, los mutilados, ex combatientes, cautivos y el resto de personal aspirante a tales plazas tenían preferencia al ser la convocatoria de carácter restringido. Finalmente, la Orden de 15 de julio de 1940 publica el escalafón de los llamados entonces Cuerpos Nacionales y por Ley de 6 de septiembre de 1940 se crea el Instituto de Estudios de Administración Local, proveyéndose poco después a la provisión de plazas. Las Juntas se encargan todavía en estas fechas tempranas de elaborar listas que suponen la depuración de estos funcionarios en cuanto los excluye de estos Cuerpos sin solución alguna (no se olvide que a la sazón se encontraba suspendida la Ley de la Jurisdicción Contencioso-Administrativa, lo que supone una aberración destacable). La centralización se impone y los Alcaldes de población hasta 10.000 habitantes son nombrados por el Gobernador civil y el resto por el Ministro de la Gobernación. Se concluye del análisis de la legislación de la época y de las vivencias que yo mismo tengo que la centralización fue absoluta ya que, ni para el nombramiento, ni para la provisión de puestos de trabajo, la Corporación tenía nada que decir. Sólo emitía un informe preceptivo pero no vinculante, y era la Dirección General de Administración local la que realizaba el resto del proceso nombrándolos después el Ministerio de la Gobernación que más tarde sería el Ministerio de Administración Territorial y hoy la propia Dirección General (recreada) del Ministerio para las Administraciones Públicas. Las funciones siguen siendo esencialmente las mismas (Vid. Reglamento de Funcionarios de Administración Local, de 30 de mayo de 1952) aunque su papel se ha reforzado muchísimo como ya he dicho. La Dirección General de Administración local tramita todos los expedientes y tiene la potestad de nombrar también a los funcionarios interinos, lo que era frecuente en aquellos tiempos por extraño que pueda parecer ${ }^{52}$. El artículo 413 de la Ley de Régimen Local, de 24 de junio de 1955, y su correlato del Reglamento de Organización, funcionamiento y Régimen Jurídico de las Corporaciones Locales, de 30 de mayo de 1952, contenían el mecanismo de la advertencia de ilegalidad que cerraba el paso a toda veleidad política de aquellos Ayuntamientos. La Ley de Bases de 5 de diciembre de 1968 no cambia sustancialmente las cosas, como no lo hará tampoco -respecto de los funcionarios locales en general- la Ley de Bases de Régimen Local, de 19 de noviembre de 1975, que sólo entró en vigor en lo referido a contratación administrativa y algunas materias de personal mediante el Real Decreto 3046/1977, de 6 de octubre. Curioso resulta que la crisis en la que entren estos Cuerpos a partir de 1980 es clarísima y así lo ha puesto de relieve A. NiETO GARCía que ha estudiado

52 J. CARRASCO Berlinchón, La función directiva de los Cuerpos Nacionales en la futura regulación de las Entidades de Régimen local, IEAL, Madrid, 1976. 
también estos temas como lo ha hecho R. MARTín MAteo que también fue interventor ${ }^{53}$.

La promulgación de la Constitución española de 27 de diciembre de 1978 supone un paso importante en el devenir de este colectivo funcionarial. De todas formas $-\mathrm{y}$ con independencia de lo poco que ahora diré-, es lo cierto que la indefinición y la crisis que vive este colectiva es infinitamente mayor que la que padecía ya en 1975. Esto lo sé por experiencia y tango muchos datos con qué avalar tal aseveración, de manera que la misma no es en absoluto gratuita. Las primeras medidas liberalizadoras empiezan con la Ley de elecciones locales, de $17 \mathrm{de}$ julio de 1978 y la celebración de las primeras elecciones locales democráticas después del franquismo, el 3 de abril de 1979, así como las conocidas sentencias del TC de 2 de febrero y 29 de julio de 1981 y el Real Decreto-ley de 16 de enero de 1981, convertido posteriormente en la Ley de 28 de octubre de 1981, que suprime controles de tutela sobre las Corporaciones locales y empieza a judicializar el sistema de relaciones interadministrativas, produciéndose paralelamente la desfiguración de los Cuerpos Nacionales como ha indicado MARTínez MARíN ${ }^{54}$. Sigue después la promulgación de la Ley 7/1985, de 2 de abril, reguladora de las Bases de Régimen Local (con un Preámbulo retórico-historicista precioso, pero tedioso en algunos extremos y que creo se debe a Parejo Alfonso) y el Real Decreto 1174/1987, de 18 de septiembre, que contiene el régimen jurídico de los funcionarios de Administración local con habilitación de carácter nacional -denominación horrorosa que introduce la nueva Ley Básica-, produciéndose la desaparición de los Cuerpos Nacionales en cuanto tales -yo diría con MARTínez MARíN que se ha producido una regionalización que va camino de la provincialización y hasta su desaparición-, con la configuración de Escalas y Subescalas -como si de un itinerario aéreo se tratase-, así como la desaparición del Cuerpo Nacional de Bandas de Música Civiles, cuyos miembros pasaron a formar parte de la plantilla de la respectiva Corporación como funcionarios propios de la misma respetándose sus derechos adquiridos (yo creo que ya no queda ninguno). Muy certeramente -como casi siempre hace este estimable profesor de nuestra disciplina- nos informa MARTíneZ Marín del hecho de que, durante el debate para la aprobación por las Cortes Generales de la Ley Básica

\footnotetext{
53 A. NiETo GarcíA, «De la República a la democracia: la Administración española del franquismo (III)», REDA n. ${ }^{\circ} 18 / 1978$, pp. 356 y ss. y R. MARÍN MATEO, «El gobierno municipal», REALA n. ${ }^{\circ}$ $227 / 1985$.

54 A. MARTínez Marín, Funcionarios locales con habilitación (pasado, presente y futuro), Ed. Tecnos, Madrid, 1999.
} 
Local, el propio José María Aznar López se opuso a la desaparición de estos funcionarios al entenderlos como pieza clave para el desarrollo de la vida local. Curiosamente, durante la tramitación del Estatuto de la Función Pública española - proyecto este que quedó definitivamente aparcado- en 1999 no vuelve a instaurarlos ${ }^{55}$.

Lo característico de esta nueva etapa es la competencia exclusiva del Estado no sólo para la configuración de los funcionarios en cuanto tales, sino también para el sistema de traslados, expedientes disciplinarios y otros extremos importantes. Únicamente intervienen las Comunidades Autónomas para la publicación de las convocatorias en sus respectivos Diarios oficiales así como para establecer un porcentaje de méritos de un 10 por 1.000 en los concursos y el nombramiento en situaciones de acumulación, agrupaciones para sostenimiento de Secretario en común y comisiones de servicios. Existen pequeñas diferencias en lo que se refiere a Euskadi -que en la práctica son todo un abismo-y la excepción de Navarra que ha mantenido su régimen singular y cuyo Gobierno Autónomo y Diputación Foral son los dueños y señores de la situación ${ }^{56}$. No sé si la habilitación nacional en materia de Universidades correrá la misma suerte que la de los Secretarios de los Ayuntamientos ${ }^{57}$.

Siguen - para desmembración de los Cuerpos Nacionales estudiados por supuesto- la Disposición Adicional Octava de la Ley 31/1991 de 31 de diciembre, de Presupuestos Generales del Estado para 1992, recogida más tarde en 18 Ley 10/1993, de 21 de abril, según la cual la libre designación será la regla en las Diputaciones Provinciales y en los municipios capitales de provincia y que superen determinadas cifras presupuestarias y el Real Decreto 731/1993, de 21 de abril, con carácter básico. Para colmo de venturas la SIC 235/2000, de 5 de octubre, declara constitucional el apartado 2 del artículo 99 de la Ley $7 / 1985$, de 2 de abril, encontrándonos en la actualidad con una casi completa desmembración de este colectivo funcionarial. Se instaura un concurso ordinario, otro unitario y la libre designación -ahora declarada constitucional siendo último hito el Real Decreto 1732/1994, de 29 de julio y la Orden Ministerial de 10 de agosto del mismo año que no dejan concebir muchas esperanzas sobre el futuro

\footnotetext{
55 Vid. Editorial de la Revista de Estudios Locales (CUNAL) n. ${ }^{\circ}$ 14/1997.

${ }^{56}$ F.J. JímENEZ LeChUGA, «La problemática movilidad de los funcionarios de Administración local con habilitación de carácter nacional», Revista de Estudios Locales (CUNAL) n. ${ }^{\circ}$ 10/1996.

57 «El inquietante futuro de los funcionarios de Administración local con habilitación de carácter nacional: el caso de la STC 235/2000, de 5 de octubre. Quo vadis?», Revista de Estudios Locales (CUNAL) n. ${ }^{\circ}$ 51/2001.
} 
de esta élite funcionarial ${ }^{58}$. La Ley 42/1994, de 30 de diciembre es también muy negativa para este colectivo, como lo es también la de 21 de abril de 1999 al atribuir al Alcalde unas competencias en materia de aprobación de Bases de concursos de traslados de funcionarios que, en mi opinión, en manera alguna les corresponden. El impacto que el Estado autonómico haya de tener finalmente sobre estos funcionarios está aun por ver pero los augurios no son nada halagüeños y así lo manifiestan muchos funcionarios diariamente ${ }^{59}$.

\section{a) Discrecionalidad administrativa}

Es precisamente aquí donde se encuentra uno de los orígenes de la problemática que presentan estos cuerpos funcionariales ya que las facultades concedidas a las Comunidades Autónomas y, sobre todo, a las Corporaciones locales, hacen que la inseguridad jurídica reine por doquier y el resultado final sea la desfiguración del colectivo funcionarial, así como la falta de respeto a los principios de capacidad, mérito, libre concurrencia y publicidad que, no debe olvidarse, también son principios aplicables a los concursos de traslados de estos funcionarios y no sólo al ingreso en el cuerpo respectivo. Por eso, esta falta de definición, hace que se produzca la intervención de tres Administraciones públicas en la regulación y gestión diaria de estos funcionarios y que la objetividad y eficacia de la actuación de la Administración no pueda lograrse (art. 103 O.E.) por mucho que el Tribunal Constitucional se haya empeñado en decirnos que el artículo 99 de la Ley, de Bases es respetuoso con la Carta Magna ${ }^{60}$.

No parece preciso entrar ahora en la definición de lo que es la discrecionalidad administrativa. Ya sabemos, en principio, que la discrecionalidad administrativa es la facultad que a la Administración concede el legislador para que, atendidas las circunstancias del caso, existiendo varias soluciones a adoptar, tomada cualesquiera de ellas, sean válidas ${ }^{61}$. Ha

\footnotetext{
58 Ley Orgánica 6/2001, de 21 de diciembre, de Universidades.

59 F.J. JiMÉNEZ LECHUGA, «El inquietante futuro de los funcionarios de Administración local con habilitación de carácter nacional el caso de la STC 235/2000 de 5 de octubre. Quo vadis?», Revista de Estudios Locales (CUNAL), n. ${ }^{\circ} 51 / 2001$ y F. SOSA WAGNER, «Los funcionarios locales con habilitación de carácter nacional: una reflexión desde la historia», Revista de Estudios Locales (CUNAL) n. ${ }^{\circ}$ extraordinario de 1997 , pp. 12 y ss.

60 Al menos, así me lo comunican muchos de ellos.

61 L. MoRELl OCAÑA, «La función pública y la habilitación nacional», Documentos INAP, $\mathrm{n}^{\circ}$ 12/1997.
} 
escrito en este sentido F. SÁINZ MoREno que, reducida, pues, la discrecionalidad los supuestos en los que la decisión se resuelve en la aplicación de criterios no jurídicos, adquiere importancia capital la determinación de la naturaleza del criterio de interés público. En los demás supuestos, cuando la decisión administrativa se funda en un criterio de naturaleza jurídica, es decir, política (ejercicio de la potestad reglamentaria, organizatoria, potestades directivas de la economía, etc.), la norma jurídica enmarca esa acción fijando sus elementos reglados: a) la existencia de la potestad, b) su extensión, e) la competencia para actuarla, y, d) el fin al que sirve. El enjuiciamiento jurídico de la potestad discrecional queda, pues, limitada al examen de esos elementos. El criterio mismo, en cambio, por no ser jurídico, queda fuera de ese examen y sólo es enjuiciado políticamente (por ejemplo, si debía o no devaluarse la peseta, si era preferible una carretera o una autopista, si la intervención administrativa en la cultura puede realizarse desde dos departamentos ministeriales o es preferible unificarla en uno sólo, si cierto terreno debe o no calificarse como zona verde, etc. ${ }^{62}$.

\section{b) Conceptos jurídicos indeterminados}

También la teoría alemana de los conceptos jurídicos indeterminados tiene importancia a la hora de legislar sobre funcionarios locales o de resolver judicialmente contiendas relacionadas con los concursos de traslados de los mismos («interés general», «interés social», «buena marcha del servicio», «honestidad», etc.) pero, como es natural, en estos casos se aplica lo que la doctrina ha venido estudiando con detenimiento durante muchos años desde E. GARCÍA DE ENTERRÍA ${ }^{63}$ hasta yo mismo en alguna ocasión ${ }^{64}$. Hace años recogió F. SÁInZ Moreno las tesis de E. GARCía DE ENTERRÍA ${ }^{65}$ sobre esta cuestión, es decir, sobre la discrecionalidad administrativa y sobre los conceptos jurídicos indeterminados ${ }^{66}$.

\footnotetext{
${ }^{62}$ E. García de Enterría, y T.R. Fernández Rodríguez, Curso de Derecho Administrativo, 2 vols., Ed. Civitas, Madrid, 2002.

${ }^{63}$ F. SÁInz Moreno, Conceptos jurídicos, interpretación y discrecionalidad administrativa, Ed. Civitas, Madrid, 1976.

${ }^{64}$ E. García de Enterría, y T.R. Fernández Rodríguez, Curso de Derecho Administrativos, 2 vols., Ed. Civitas, Madrid, 2002.

${ }^{65}$ F.J. JiMÉNEZ LeChUGA, «Estado social y democrático de Derecho y actividad administrativa. El binomio eficientismo-garantismo como solución conciliatoria», Revista de Estudios Locales (CUNAL) $\mathrm{n}^{\circ} 56 / 2002$.

${ }^{66}$ F. SÁInz Moreno, Conceptos jurídicos, interpretación y discrecionalidad administrativa, Ed. Civitas, Madrid, 1976.
} 
Hace años que el profesor GARCÍA DE ENTERRÍA se refería a estas cuestiones y por lo que a la discrecionalidad administrativa se refiere, decía que la atribución de estas potestades puede realizarse de dos modos: a) precisando todas las condiciones del ejercicio de la potestad (potestad reglada, cuyo ejercicio por la Administración consiste en constatar los elementos legalmente definidos); b) o bien definiendo algunas de las condiciones del ejercicio de la potestad, pero remitiéndose, en cuanto a otras, a la estimación subjetiva de la Administración (potestad discrecional cuyo ejercicio implica realizar una estimación por la Administración; no es pues, un supuesto de libertad frente a la norma, sino de remisión legal). No hay, pues, discrecionalidad al margen de la Ley; sólo existe en virtud de una Ley y en la medida en que esta Ley lo haya dispuesto. Puede, además, haber otros. Por eso en toda potestad discrecional siempre existen elementos regulados por la ley, al menos cuatro: a) la existencia misma de la potestad, b) su extensión, c) la competencia, y, d) el fin. Puede, además, haber otros (tiempo, fondo, forma, etc.). Ello no implica, sin embargo, la desaparición de la discrecionalidad. La apreciación de circunstancias singulares, la estimación de la oportunidad completa, en el ejercicio del poder público, es indeclinable y ello alimenta inevitablemente la técnica del apoderamiento discrecional. Sustancialmente eso es la política, la cual es ilusorio pretender desplazar del gobierno de la comunidad ${ }^{67}$.

En cambio, para el mismo profesor, que se hace eco de las tesis alemanas sobre la materia, los conceptos jurídicos indeterminados, la aplicación de estos conceptos implica subsumir una categoría legal a unas circunstancias legales determinadas. Se trata de aplicar la Ley. Es un proceso reglado que se agota en el proceso intelectivo de comprensión de una realidad en el sentido de que el concepto jurídico indeterminado ha pretendido, proceso en el que no intervine ninguna voluntad de aplicación del aplicador. Las consecuencias de esta tesis son bien claras. Por tratarse de la interpretación y aplicación de la ley que ha creado el concepto, el Juez puede fiscalizar tal aplicación en orden a si se ha llegado a la única solución justa que la ley permite. Puede surgir, sin embargo, una mayor dificultad cuando se trata de la aplicación de nociones jurídicas en aquellos casos que hay que conceder a quien opera con el concepto no tiene otra solución que la de solucionar supuestos difíciles que a su vez crean una dificultad de control (no se olvide el «halo conceptual»). Este autor aplica la técnica de los conceptos jurídicos indeterminados a aquellos casos en que el presupuesto de hecho del acto administrativo es una situación compleja o ambigua y, sobre todo, a la

67 F.M. Clavero Arevalo, «La manifiesta ilegalidad de los actos administrativos», REVL n. ${ }^{\circ}$ 100 . 
motivación de los actos administrativos; cuando el artículo 43 de la vieja Ley de Procedimiento Administrativo imponte la motivación de algunos actos administrativos obligaba a dar razón plena del proceso lógico y jurídico que ha determinado la decisión. Y entonces no cabe sustituir un concepto jurídico indeterminado que esté en base de la ley de cuya aplicación se trata, por otro igualmente indeterminado: habrá que justificar la aplicación de dicho concepto a las circunstancias de hecho de que se trata; otra cosa no es expresar un motivo, es más bien formular una conclusión ${ }^{68}$. Estas tesis del citado autor no han sido aún superadas y responden, en lo sustancial, con las mismas que recoge el Derecho alemán.

\section{LA SENTENCIA DEL TSJA DE 23 DE JUNIO DE 2003 (SALA DE LO CONTENCIOSO-ADMINISTRATIVO DE GRANADA, SECCIÓN PRIMERA)}

Es llegado ya el momento de entrar en el comentario de esta sentencia del TSJA, con sede en Granada, $\mathrm{n}^{\circ}$. 411/2003, de 23 de junio, dimanante del rollo de apelación $n$. $^{\circ} 293 / 2001$, que confirme la de primera instancia $n$. $^{\circ}$ 72/2001, de 21 de marzo, dictada por el Juzgado de lo Contencioso-Administrativo n. $^{\circ} 3$ de los de Granada. Si traigo este asunto hoy a la consideración de los lectores de esta revista, no es solamente movido por el prurito de comentar supuestos que afectan de manera directa el colectivo de funcionarios locales con habilitación de carácter nacional, sino también porque este proceso fue de mi autorepresentación y dirección técnica, interviniendo conmigo sólo incidentalmente otra compañera Maria Nieves Sáez Ortega a la sazón Secretaria del Ayuntamiento de Huétor Tajar (Granada), aunque, al presentarse tardíamente, no fue tenida como parte procesal por no contemplar esta figura adhitiva la Ley 29/1998, de 13 de julio, según la jueza. Resumidamente, los hechos fueron los siguientes. Interpuesto recurso por el que esto suscribe se admitió la demanda, solicitando el actor don FranciscoJavier Jiménez Lechuga, que tras los trámites legales, se dictase sentencia por la que se declarase la disconformidad a Derecho del Baremo específico aprobado por la Resolución del Diputado Delegado del Área de Recursos Humanos de la Excma. Diputación Provincial de Granada, de 8 de febrero de 2000 que se combate ante el orden jurisdiccional contencioso-administrativo. Se reclamó el expediente a la Corporación provincial que lo remitió y, tras diversas vicisitudes procesales que no son ahora del caso -siendo la más relevante la inadmisión como parte de la funcionaría anteriormente citada-,

${ }^{68}$ F. SÁInZ MoReno, Conceptos jurídicos, interpretación y discrecionalidad administrativa, Ed. Civites, Madrid, 1976. 
se recibió el pleito a prueba y se señaló fecha para la vista. En definitiva, se combatían los méritos específicas que la citada resolución establecía y que eran: a) teniendo como principal cometido el desempeño de las funciones reservadas a habilitados de carácter nacional en entidades locales exentas, se valorará el haber desempeñado el puesto de Secretario-Interventor, en virtud de nombramiento efectuado por autoridad competente, en Entidades locales con población inferior a 500 habitantes y presupuesto inferior a 20.000 .000 ptas. Por cada mes de servicio 0'40 puntos con un máximo de 2 puntos, b) dadas las peculiaridades propias del desempeño de las funciones reservadas a habilitados de carácter nacional en los Servicios de Asistencia a Municipios, se valorará el haber desempañado el puesto de Secretario-Interventor, en virtud de nombramiento efectuado por el procedimiento legalmente establecido para dicho puesto, en Servicio de Asistencia, de Asesoramiento e Inspección de las Corporaciones locales, por cada mes de servicios, 0'40 puntos, con un máximo de dos puntos, c) debiendo atender simultáneamente desde los puestos convocados el desempeño de funciones reservadas a habilitados de carácter nacional en más de una Entidad local, se valorará el haber desempeñado el puesto de Secretario-Interventor, en virtud de nombramiento efectuado por autoridad competente, en más de una Entidad local de forma simultánea. Por cada mes de servicios 0'40 puntos, con un máximo de 2 puntos, y d) en atención a lo dispuesto en el artículo 14.2 del Real Decreto 1732/1994, la puntuación mínima que han de obtener los concursantes para la adjudicación de los puestos es de 7'5 puntos ( 25 por 100 del total de la puntuación obtenida). En los razonamientos jurídicos de la Sentencia de instancia n. ${ }^{\circ} 72 / 2001$, después de rechazar las dos causas de admisibilidad opuestas por la Diputación provincial demandada (extemporaneidad del recurso e incapacidad del actor), se entra a conocer del asunto, añadiéndose, en síntesis, que, por lo que se refiere al primer apartado del Baremo aprobado por la Diputación Provincial las alegaciones realizadas por el actor (Francisco-Javier Jiménez Lechuga), consistentes en entender que el criterio poblacional fijado en dicha base - prestar servicios en poblaciones de menos de 500 habitantes-, resulta contraria a los principios constitucionales de igualdad (art. 14 C.E.), objetividad, imparcialidad, mérito y capacidad y publicidad (art. 23.2 C.E.) porque injustificadamente discrimina a los Secretarios que hayan desempañado sus servicios en poblaciones con mayor número de habitantes y que la Subescala de Secretarios-Interventores es para municipios de menos de 5.000 habitantes, entendiendo el Juzgado que debe desestimarse ya que la SIS $235 / 2000$, de 5 de octubre ${ }^{69}$ dispone que la reser-

\footnotetext{
${ }^{69}$ FJ. JimÉNEZ LeCHUGA, «El inquietante futuro de los funcionarios de Administración local con habilitación de carácter nacional: el caso de la STC 235/2000, de 5 de octubre. Quo vadis?», Revista de Estudios Locales (CUNAL) n. ${ }^{\circ}$ 51/2001.
} 
va de un 25 por 100 en la valoración global del concurso a las Corporaciones locales en atención a las características del puesto de trabajo, es perfectamente legal, no necesitando reserva de Ley los baremos correspondientes, añadiendo que dichas Corporaciones locales, en estos casos, se encuentran respaldadas con el principio de autonomía local y que el control judicial se realiza únicamente en base a si el baremo se adecúa o no a las especificidades del puesto, no pudiendo desembocar en un excesivo encorsetamiento que anule la discrecionalidad otorgada por el legislador, además de la excepción o exención de cubrir tales plazas según el artículo 4 del Real Decreto 1732/1994. También se refiere a que la fijación del Baremo no prejuzga al candidato, por lo que no se opone a la doctrina del Tribunal Constitucional.

Es muy discutible todo lo que afirma esta jueza en este razonamiento jurídico. En primer lugar, la discrecionalidad ha de ser mínima en estos extremos, con independencia de lo que establece la doctrina fijada por el IC en la sentencia dicha y que yo mismo comenté en su momento en esta misma revista, ya que se hayan en juego principios constitucionales superiores que son los que componen la llamada carrera administrativa, que así se ve menguada, cuando no anulada de tacto, además de que, los principios de capacidad y mérito padecen sobremanera, así como el de objetividad en la actuación administrativa, lo que la jueza no tiene en cuenta según se puede colegir de lo que hasta el momento llevo dicho.

En segundo lugar, y esto no ha querido verlo la jueza, es evidente que, en el caso de autos, podría haber existido una clara y manifiesta desviación de poder. Sin embargo, como en el período probatorio, no se admitió la asistencia del Diputado Delegado para testificar, esto no puedo esclarecerse. Además, parece sospechoso que ya estas plazas estuviesen cubiertas interinamente por el propio presidente del Colegio provincial y otro funcionario, según consta en el expediente, por mucho que la defensa de la Diputación granadina, sostuviese que no se había puntuado a los participantes por este apartado del baremo. Es de sospechar que existía ya un retrato anticipado de los futuros adjudicatarios de la plaza, lo que resulta contrario a la doctrina del Tribunal Constitucional que la propia jueza cita en su sentencia objeto ahora de este comentario jurisprudencial.

Precisamente el segundo punto de la sentencia queda ya comentado aunque la jueza no tenga escrúpulo alguno en admitir que la interinidad de aquéllos no supone ningún tipo de prevalencia al no haber sido valorados los concursantes precisamente por este apartado del baremos ¿Cómo 
explicar, pues, la existencia del mismo? Resulta absurdo y, cuando menos, sospechoso $^{70}$.

En lo que se refiere al tercer apartado del Baremo, alega el demandante que dicha base parece contraria al principio de objetividad, mérito y capacidad (art. 17 R.D. 1732/1994) porque el puesto podría desempeñarlo con igual eficacia un funcionario con habilitación nacional que hubiere prestado servicios de veinte años en un municipio de 4.500 habitantes, concluyendo, por su parte, la jueza, que, ciertamente, esta Base también valora esta circunstancia teniendo en cuenta que pueden haber prestado servicios en Agrupaciones de municipios y que seis municipios precisamente están exentos de cubrir por el procedimiento habitual tales plazas. La verdad es que el razonamiento de la sentencia de instancia no es convincente y es contrario a Derecho -por mucho que la sentencia de apelación a la que luego aludiré conforme ésta-, toda vez que la discriminación que se produce es clara. Y me parece que los funcionarios definitivamente nombrados para SAM de la Diputación de Granada no han estado en municipios con muchos más habitantes de los 500 (quizás como mucho 1.500 habitantes).

En cuanto al quinto, es decir, cuarto punto de las Bases, esto es, la exigencia de un mínimo de 7' 5 puntos para poder obtener alguna de las plazas (lo que representa un 25 por 100 sobre el total) el argumento de artículo 14 del Real Decreto 1732/1994, de la jueza es de pie forzado y delirante. Con la solo invocación del 29 de julio, pretende salvar el problema, entendiendo tal exigencia ajustada a Derecho. Es evidente que, un funcionario con habilitación nacional reciente ingresado quizás no disponga ni de siquiera esa puntuación. Cabría preguntarse si, a la vista de los artículos 6 de la Ley Orgánica del Poder Judicial y 62 de la Ley 30/1992, de 26 de noviembre, no debería haberse declarado nulo de pleno derecho este apartado, si bien es verdad que en el conjunto del concurso objeto de la sentencia este no decidía nada en cuanto todos los aspirantes superaban esa puntuación. Pero hay que tener presente que la superaban no ex ante (principio de igualdad ante la ley y en la ley) sino ex post tacto. Esto no lo ha visto la jueza. Finalmente, acaba desestimando el recurso interpuesto por el autor sin expresa condena en $\operatorname{costas}^{71}$.

Se pidió la suspensión del acto que fue denegada por el Juzgado de lo Contencioso n. ${ }^{\circ} 3$ de los de Granada y confirmada la denegación por Sen-

\footnotetext{
70 C. Chinchilla Marín, La desviación de poder, Ed. Civitas, Madrid, 1989.

71 La condena en costas no ha recibido la regulación debida en la Ley 29/1998, de 13 de julio.
} 
tencia del Tribunal Superior de Justicia de Andalucía con sede en Granada . $^{\circ}$ 270/2001, sobre lo que no hay que extenderse pues estas medidas sí parecen lógicas y ajustadas a Derecho en cuanto ningún perjuicio se originaba al recurrente aunque los funcionarios nombrados, en todo caso, hubiesen seguido allí prestando servicios, no causándose, en consecuencia, tampoco, ningún perjuicio para ellos. Lo que todavía no tiene claro quien esto escribe es cómo llegaron allí y quiénes los recomendó.

Recurrida en apelación la sentencia comentada, se dictó otra por la Sección Primera de la Sala de lo Contencioso-Administrativo del Tribunal Superior de Justicia de Andalucía, con sede en Granada, n. ${ }^{\circ}$ 411/2003, de 23 de junio, en le que se da cuenta de la interposición del recurso por don Francisco Javier Jiménez Lechuga contra la sentencia de instancia, resumiendo que él mismo está legitimado para haber participado -como efectivamente lo hizo- en el concurso ordinario de traslados convocado por la Dirección General para la Administración Local de 24 de abril de 2000 (BOE de 26.05.00). En los fundamentos jurídicos de la sentencia de la Sala de Granada se dice que no se formulan motivos nuevos de apelación que se repiten los de instancia por lo que no puede prosperar la mera invocación del artículo 85 LJCA.

Aquí hay que discrepar del parecer de la Sala de Granada, ya que la inadmisión de la comparecencia del titular del órgano que dictó la resolución ni de ninguno de los implicados en el caso, impedía, como era de prever, la demostración de una posible desviación de poder. Y, si bien es verdad que esta «prueba diabólica» corresponde al recurrente, no lo es menos que no se le ofreció oportunidad alguna de hacerlo y, de ser ciertas las sospechas del recurrente -como tantas veces ha ocurrido en otros muchos Ayuntamientos- so capa de justicia, se habrá cometido una injusticia material clara y ya inevitable. Como no se conocen los elementos integrantes de la decisión del órgano administrativo que dictó el acto, ni la forma en que se reclutaron interinamente estos funcionarios, es lo cierto que los Tribunales han podido dar la razón a quienes inicialmente estaban carentes de ella pues el período probatorio puramente no ha existido. $\mathrm{Y}$ eso que los interesados estaban presentes en la Sala de Vistas del Juzgado $\mathrm{n}^{\mathrm{o}} .3$ de los de Granada y el recurrente pudo reconocerlos muy bien. Y es curioso como afirma la sentencia de la Sala de Granada que no se combatieron las razones de la sentencia de instancia cuando tal cosa era innecesaria pues se combatían por sí mismos.

En definitiva, la sentencia de la Sala confirma la de instancia sin ni siquiera tener presente que no se realizaron las pruebas que se solicitaron cayendo en un formalismo extremo que nada dice sobre la justicia mate- 
rial del asunto enjuiciado. Hay que tener presente, por lo demás, que no puede discreparse enteramente de la Sala por una razón bien elemental. El positivismo jurídico, el legalismo exacerbado y la falta de una definición legal no sólo de estos funcionarios sino de toda la función pública española, hace que el jurista se enfrente y encuentre con resoluciones judiciales tan alejadas de la justicia material del caso concreto como las presentes $^{72}$. Prueba de lo que vengo escribiendo lo es que no son muchas las sentencias que han condenado a las Administraciones afectadas en este terreno. Además $-\mathrm{y}$ esto es más chocante todavía- el grado de judicialización de las relaciones funcionariales ha aumentado desde 1990 hasta el momento en un porcentaje de un 500 por 100 según la última memoria del Fiscal General del Estado por lo que a los recursos contencioso-administrativos se refiere y a la Memoria del Consejo General del Poder Judicial del último año.

\section{CONCLUSIONES}

Es llegado ya el momento de formular unas reflexiones finales sobre la función pública y los funcionarios con habilitación nacional desde la perspectiva de los principios informadores del Estatuto de la Función pública que está por promulgarse y que han sido analizados en este estudio en la medida en que ello era necesario para la cabal comprensión de la situación de encrucijada en que se encuentran estos cuerpos funcionariales en la actualidad y que buena parte de la doctrina viene ya exponiendo con una justificada preocupación y alarma desde hace algunos años ${ }^{73}$. Veamos:

Primero.- La Administración pública actúa con objetividad los intereses generales. Para ello, el acceso a cargos y funciones públicas ha de ir presidido del respeto a los principios de mérito, capacidad, libre concurrencia y publicidad en los término nos analizados por la doctrina y por el propio Tribunal Constitucional según han quedado expuestos.

Segundo.- Es absolutamente imprescindible la promulgación definitiva del Estatuto de la Función pública. En este terreno el caos es absoluto, no sólo en el proceso de selección y formación de funcionarios, sino en su régimen jurídico y, lo que es todavía más alarmante, de ese tosco derecho disciplinario que es en muchos extremos ilegal e incluso inconstitucional.

\footnotetext{
72 T.R. FERNÁNDEZ RoDRÍGUEZ, «Juzgar a la Administración contribuye también a administrar», REDA n. ${ }^{\text {o } 76 / 1992 .}$

73 E. Corral García, «Los secretarios: pasado, presente y futuro», Revista de Estudios Locales (CUNAL) n. ${ }^{\circ} 12 / 1996$.
} 
Tercero.- La discrecionalidad administrativa y los conceptos jurídicos indeterminados son dos conquistas de la doctrina que los Tribunales deben tener en cuenta en el momento de decidir asuntos como el presente porque no es posible llegar a situaciones tan injustas como la que acabo de describir. Y tampoco pueden los funcionarios pasar largos años de sus vidas embarcados en pleitos interminables para que, finalmente, sólo logre una victoria pírrica y se burle el o la realización de la justicia material que es de los que se trata.

A esto ha contribuido en gran medida el positivismo jurídico, el legalismo exacerbado y el alto grado de tonificación y complicación de las relaciones sociales ${ }^{74}$. En un Estado de Derecho como el nuestro es necesario apostar decididamente por la ampliación del arbitrio judicial y la discrecionalidad judicial si queremos que efectivamente se cumpla la cláusula general contenida en el artículo 1.1 C.E. Los funcionarios -al igual que el resto de los ciudadanos- no pueden pasarse la vida pleiteando en un combate absurdo contra el Estado que a nada conduce finalmente.

Cuarto.- La Sentencia 72/2001, de 21 de marzo, es errónea y equivocada -como lo es también la confirmatoria en apelación comentada en este estudio-, ya que no admite las pruebas propuestas y las sospechas de desviación de poder sólo se han quedado en eso ${ }^{75}$.

Quinto.- La libre designación, las interinidades y el baremo de méritos específicos para este tipo de funcionarios deben desaparecer inmediatamente. En caso contrario, los que desaparecerán serán los propios funcionarios y en este sentido se han decantado ya A. NieTo GARCíA ${ }^{76}$ y A. MARTínEZ MARín ${ }^{77}$, entre otros, como lo he hecho yo mismo y E. CORRAL GARCÍA $^{78}$.

\footnotetext{
74 A. Nieto García, El arbitrio judicial, Ed. Ariel, Barcelona 2000.

75 También quiero recordar que yo mismo participé en otro concurso ordinario de traslados para la Diputación Provincial de Granada (Servicio de Asistencia a Municipios) en 1995 sin obtener plaza allí (se convocaban 2). Y, modestamente, sin menosprecio de lo los adjudicatarios -cuyos nombres ahora silenciaré-, es seguro que tengan bastantes menos méritos que yo mismo. Esto ha hecho que -pese al problema sempiterno en España del desempleo- muchos funcionarios con habilitación hayan «desertado», perdiendo así la Administración local un capital humano inestimable. De esta forma, sólo esta forma, sólo los más mediocres permanecen.
76 A. Nieto García, Los primeros pasos del Estado constitucional, Ed. Ariel, Barcelona, 1996.
77 A. MARTínez MARín, Funcionarios locales con habilitación (pasado, presente y futuro), Ed. Tec- nos, Madrid, 1999.
${ }^{78}$ E. CoRral García, «Los secretarios: pesado, presente y futuro, Revista de Estudios Locales $(C U N A L) »$ n. ${ }^{\circ} 12 / 1996$.


Hasta aquí llega la exposición de este asunto tan apasionante y tan importante para la Administración pública española. Una urgente reforma es necesaria para que la función pública en general, y la función pública local en particular, se adapten a lo que la sociedad demanda de ellos en un Estado social y democrático de Derecho que propugna como valores superiores de su ordenamiento jurídico la libertad, la igualdad, la justicia y el pluralismo político. No se puede seguir así por más tiempo. Por otro lado, no conozco la razón por la cual algunos juristas han sido excelentes escritores por lo que su lectura debe ser recomendada para que no todo sea Derecho $^{79}$.

Espero que los lectores de la revista puedan conocer este articulo lo antes posible. Esperemos ${ }^{80}$.

\section{BIBLIOGRAFÍA}

A. Martínez Marín, Régimen jurídico de los funcionarios, Ed. Tecnos, Madrid, 2001.

E. García de EnTERría, y T.R. Fernández Rodríguez, Curso de Derecho Administrativo, 2 vols., Ed. Civitas, Madrid, 2002.

A. Martínez Marín, Funcionarios locales con habilitación (pasado, presente y futuro), Ed. Tecnos, Madrid, 1999.

J. Fialaire, La gestion des services publics, París, 1998.

R. Romi, Droit et administration de l'environnement, $5^{\mathrm{a}}$ edición, Montchrestien, París, 2003.

E. Corral García, «Los secretarios: pasado, presente y futuro», Revista de Estudios Locales (CUNAL) n. ${ }^{\circ}$ 12/1996.

F.J. JimÉnez LeChugA, «El inquietante futuro de los funcionarios de Administración local con habilitación de carácter nacional: el caso de

\footnotetext{
79 E. Hemingway, París era una fiesta, Ed. Seix Barcelona, Barcelona, 2003 y J.R. JimÉNEz, Platero y yo, Ed. Planeta DeAgostini, Barcelona, 2003. En este caso, al menos que yo sepa, ninguno de los dos era jurista.

${ }^{80}$ Termino de escribir estas páginas el 25 de junio de 2003 habiéndose celebrado ya la importante Cumbre de Salónica (recuérdese el Proyecto de Constitución Europea elaborado por un Equipo presidido por Valéry Giscard d'Esteing) y se sabe que en marzo de 2004 se celebrarán elecciones generales en España. Esperemos que los lectores conozcan este estudio antes de esas fechas.
} 
la STC 235/2000, de 5 de octubre. Quo vadis?», Revista de Estudios Locales (CUNAL) n. ${ }^{\circ}$ 51/2001.

- «La problemática movilidad de los funcionarios de Administración local con habilitación de carácter nacional», Revista de Estudios Locales (CUNAL) n. ${ }^{\circ} 10 / 1996$.

- «Estado social y democrático de Derecho y actividad administrativa. El binomio eficientismo-garantismo como solución conciliatoria», Revista de Estudios Locales (CUNAL) n. ${ }^{\circ}$ 56/20023.

A. Bullón Ramírez, Historia del Secretariado de Administración local, Abella, Madrid, 1968.

J.J. Villa y Dorbe, El Secretariado de Administración local, Madrid, 1968.

A. Nieto García, El arbitrio judicial, Ed. Ariel, Barcelona, 2000.

A. Gallego Anabitarte, Formación y enseñanza del Derecho público en España (1769-2000), Ed. Marcial Pons, Madrid, 2002.

S. GonZÁLEZ-VARAS IBÁÑEZ, La Jurisdicción Contencioso-Administrativa en Alemania, Ed. Civitas, Madrid, 1993.

J. Gascón y Marín, Tratado de Derecho Administrativo, 2 vols., Madrid, 1947.

A. Nieto-García, Los primeros pasos del Estado constitucional, Ed. Ariel, Barcelona, 1996.

L. MOREll OCAÑA, «La función pública y la habilitación nacional», Documentos INAP n. ${ }^{\circ}$ 12/1997.

Fernando SÁINZ Moreno, Conceptos jurídicos, interpretación y discrecionalidad administrativa, Ed. Civitas, Madrid, 1976.

J. MeILAN GiL, La función pública española en la doctrina científica, BOE, Madrid, 1962.

J.R. PARADA VÁzQUEZ, «Empleo público y globalización de la economía», $D A$ n. ${ }^{\circ}$ 245/1995 y F. SÁrnz Moreno, «El Estatuto de la Función Pública después de la STC 99/1987, de 11 de junio y de la Ley 23/1988, de 28 de julio, RAP n. ${ }^{\circ}$ 127/1988 y J.M. TRAYTER JIMÉNEZ, Manual de Derecho disciplinario de los funcionarios públicos, Ed. Marcial, Pons, Madrid, 1992. 


\section{Crónicas y Documentos}

